\title{
Skipulagsform íslenskra fyrirtækja í sveiflukenndu viðskiptaumhverfi 2007-2016
}

\author{
Ásta Dís Óladóttir, Ingi Rúnar Eðvarðsson og Guðmundur Kristján \\ Óskarsson $^{1}$
}

\begin{abstract}
Ágrip
Markmið pessarar greinar er að skoða hvort efnahagssveiflur hafi áhrif á skipulagsform (skipurit) íslenskra fyrirtækja. Bornar eru saman kannanir höfunda frá árinu 2007 og árið 2016 og greint hvort efnahagssveiflur hafi haft áhrif á skipulagsform viðkomandi fyritækja. Spurt var í síðari könnuninni hvort einhverjar skipulagsbreytingar hefðu orðið á undanförnum fimm árum, eða til ársins 2011, áður en uppsveifla hófst að nýju í íslensku efnahagslífi. Greinin byggir á niðurstöðum netkannana sem framkvæmdar voru af Rannsóknar- og próunarmiðstöð Háskólans á Akureyri árið 2007 og af Viðskiptafræðideild Háskóla Íslands árið 2016. Svör bárust frá stjórnendum 222 fyrirtækja árið 2007 og stjórnendum 120 fyrirtækja árið 2016. Svarhlutfall var pví 46,15\% árið 2007 og 24,4\% árið 2016. Samanburður kannananna bendir til pess að hagsveiflur, bæði uppsveiflur og samdráttur í efnahagslífi, hafi ekki haft mikil áhrif á stjórnskipulag peirra fyrirtækja sem tóku pátt í rannsókninni. Pó er pess að geta að 36,4\% fyrirtækja gripu til samruna við önnur fyrirtæki, yfirtöku á öðru fyrirtæki eða annarra skipulagsbreytinga eftir efnahagshrunið árið 2008, en stjórnendur voru beðnir að greina frá skipulagsbreytingum sem orðið hefðu síðastliðin fimm ár. Fyrirtækin hafa fleira starfsfólk hin síðari ár, stjórnendur peirra eru með meiri menntun og fleiri konur eru við stjórnvölinn nú en voru fyrir hrun. Stærð fyrirtækjanna hefur áhrif á ýmsa pætti í skipulaginu. Stærri fyrirtæki hafa meiri formfestu, sérhæfingu og hafa frekar sampykkt stjórnskipulag, pau hafa prjú eða fleiri stjórnprep og eru frekar skipulögð í anda fléttuskipulags. Pá kemur íljós að eftir pví sem rekstrarumhverfi fyrirtækjanna er stöđugra, peim mun meiri líkur eru á pví að starfaskipulag sé við lýði.
\end{abstract}

1 Ásta Dís Óladóttir er lektor við Viðskiptafræðideild Háskóla Íslands, Guðmundur Kristján Óskarsson er dósent við Viðskiptadeild Háskólans á Akureyri og Ingi Rúnar Eðvarðsson er prófessor við Viðskiptafræðideild Háskóla Íslands.

This work is licensed under a Creative Commons Attribution 4.0 License. 


\begin{abstract}
The aim of this article is to compare the organisational structure (organisational charts) of Icelandic companies in the period 2007-2016. Surveys by the authors from 2007 and 2016 are compared and an analysis carried out of whether economic fluctations affected the companies' organisational structure. The article is based on the results of an online survey administered 2by the University of Akureyri Research Centre in 2007 and the Faculty of Business Administration at the University of Iceland in 2016. The managers of 222 companies responded to the survey in 2007 and 120 companies responded to the survey in 2016 and the response rate was $46,15 \%$ in 2007 and $24,4 \%$ in 2016 . The comparison of the surveys indicate that economic fluctations do not have much influence on the organisational structure of the companies that participated in the research. However, it needs to be mentioned that $36.4 \%$ of the firms did merge with other firms, did take over other companies or made other organisational changes after the financial crisis in 2008. The companies have more employees after the collapse, their managers are more educated, and more women are in positions of power than (there were) prior to the collapse. The size of the companies influences various aspects of their organisation. Larger companies are more formal and have more specialisation and a defined organisational structure, have three or more management levels and are more likely to be organised in accordance to a matrix structure. Also, it is revealed that a more stable operational environment increases the probability that functional structure is in place.
\end{abstract}

\title{
JEL flokkun: M1;L2
}

Lykilorð: Skipulagsform, skipurit, rekstrarumhverfi, Ísland.

Key words: Organisational structure, organisational chart, operational environment, Iceland

\section{Inngangur}

Pað er óhætt að fullyrða að miklar breytingar hafi orðið í umhverfi íslenskra fyrirtækja á tæpum áratug. Íslensk fyrirtæki hafa frá pví að höfundar hófu rannsóknir á skipulagsformi peirra gengið í gegnum mikla umbrotatíma (Ingi Rúnar Eðvarðsson og Guðmundur Kristján Óskarsson, 2008). Íslenskt viðskiptalíf hefur á árunum 2007-2016 farið í gegnum mikið hagvaxtarskeið með umtalsverðri útrás, gengið í gegnum alpjóðlega fjármálakreppu sem leiddi til efnahagshruns (Arney Einarsdóttir, Katrín Ólafsdóttir og Auður Arna Arnadóttir, 2011; Ásta Dís Óladóttir, 2010; Gylfi Magnússon, 2010) og er nú á tiltölulega hröðu uppbyggingarskeiði að nýju (Alpýðusamband Íslands, 2016; Hagstofa Íslands, 2016a). Pví vaknaði sú spurning hvort skipulag fyrirtækja tæki mið af pví sem væri að gerast í umhverfi peirra, eða hvort pað væri einangrað við fyrirtækin sjálf og að umhverfið hefði par lítil áhrif.

Fyrirtæki styðjast við stjórnskipulag sem verkfæri til að ná fram ákveðinni sýn sem pau hafa varðandi framtíðina og til að ná peim markmiðum sem stefnt er að. Í stjórnskipulagi er fyrirkomulag aðgerða og vinnuferla formfest, boðleiðir skilgreindar sem og tengsl á milli manna og deilda. Pví skiptir máli að skipulag fyrirtækja taki mið af pví hlutverki og peirri stefnu sem starfsemi peirra byggist á. Að sama skapi hefur skipulagið mikla pýðingu varðandi árangur fyrirtækja, t.d. að upplýsingar berist hratt um fyrirtækið, að ákvarðanir dragist ekki á 
langinn og að aðgerðir séu samhæfðar, en slíkt skiptir miklu máli, sérstaklega ef umhverfið einkennist af óvissu (Jones, 2013).

Í raun má segja að of lítið hafi verið fjallað um skipulag íslenskra fyrirtækja fram að pessu, en frá síðustu rannsókn höfunda hafa til að mynda Einar Svansson og Runólfur Smári Steinpórsson (2012) rannsakað skipulag íslenskra fyrirtækja 2004-2007. Par fjalla peir um próun á skipulagi, ferlum og umfangi í starfsemi 200 stærstu íslensku fyrirtækjanna á ofangreindum árum, par sem markmiðið var að kanna hvort ný skipulagsform væru að ryðja sér til rúms eða hvort ný form væru að próast samhliða eldri formum.

Í pessari grein er kynnt rannsókn á stjórnskipulagi íslenskra fyrirtækja sem framkvæmd var sumarið 2016 og hún borin saman við rannsókn frá árinu 2007 (Ingi Rúnar Eðvarðsson og Guðmundur Kristján Óskarsson, 2008)). Markmið greinarinnar er að bera saman skipulagsform (skipurit) íslenskra fyrirtækja á tímabilinu 2007-2016 með pví að bera saman tvær kannanir og greina hvort efnahagssveiflur hafi haft áhrif á skipulagsform peirra. Kannanirnar ná yfir uppgangsskeið árið 2007, efnahagshrun árið 2008 og upphafið að nýju hagvaxtarskeiði, frá árinu 2011. Markmiðið er einnig að kanna hvort og pá hvaða áhrif stærð fyrirtækja hafi á skipulag peirra og skoðað er hvort kynjahlutfall stjórnenda hafi eitthvað breyst frá fyrri rannsókn höfunda.

Annar hluti greinarinnar gerir grein fyrir fræðilegri umræðu um skipulagsheildir og umhverfi peirra. Priðji hluti snýr að rannsóknaraðferðum og sá fjórði lýsir helstu niðurstöðum rannsóknarinnar. Pá taka við umræður.

\section{Fræðileg umræða}

Skipulagsheild, fyrirtæki, stofnun eða félagasamtök, er „félagsleg heild sem er markmiðsdrifin, er hönnuð sem skipulagt og samhæft aðgerðarkerfi og er tengd ytra umhverfi sínu" (Daft, 2007, bls. 10 ). Skipulag, markvissir starfshættir og stjórnun skipta miklu máli svo að starfsemi fyrirtækja sé skilvirk, skili peim markmiðum sem stefnt er að og starfsfólk vinnur að í sameiningu (Buchanan og Huczynski, 2013). Í stjórnskipulagi er fyrirkomulag aðgerða og vinnuferla formfest, t.d. eru boðleiðir skilgreindar sem og tengsl milli starfsfólks og deilda. Pá er tekin ákvörðun um pað á hvers konar samræmingarkerfi skipulagið skuli byggjast .

Samkvæmt Duncan (1979) er skipulag fyrirtækja meira en einungis rammar á einhverri fallegri mynd. Рað lýsir mynstri samhæfingar og samskipta innan og utan fyrirtækisins og pað tengir saman verkefni og mannauð skipulagsheildarinnar svo hún geti pjónað tilgangi sínum. Í raun má segja að stjórnskipulag fyrirtækja hafi tvö markmið. Раð tryggir upplýsingastreymi og pað dregur úr óvissu varðandi ákvarðanatöku. Starfsfólk veit hvert pað á að leita og pað veit hver pað er sem tekur viðeigandi ákvarðanir innan fyrirtækisins (Neubert, Hunter og Tolentino, 2016). Í stjórnskipulagi fyrirtækis eru eftirtalin atriði ákveðin:

- Hvaða valdabrautir og formlegu samskipti skuli vera á milli starfsmanna fyrirtækis, p. á. m. stigveldi og stjórnunarspönn.

- Hvaða starfsmenn skuli tilheyra hvaða deildum og hvaða deildaskipting skuli vera í fyrirtækinu.

- Hvaða kerfi, m.a. til upplýsingavinnslu og boðmiðlunar, skuli tryggja árangursrík samskipti og samræmingu í starfsemi fyrirtækisins (Jones 2013, bls 30; Daft, 2007, bls. 86). 
Skipulagslegum sérkennum fyrirtækja er vanalega lýst innan skipulagsfræða með hugtökunum skipulagsvídd (e. structural dimensions) og samhengisvídd (e. contextual dimensions). Skipulagsvídd nær yfir pætti sem lýsa innri einkennum fyrirtækja, svo sem pví hversu formlegt fyrirtækið er (skráðar reglur, stefnuskjöl, starfslýsingar, skrifleg samskipti, handbækur o.fl.), sérhæfingu viðfangsefna, valdaskipan, miðstýringu ákvarðana, menntun starfsmanna og hlutfalli starfsmanna í ólíkum störfum (Child, 1972; Daft, 2013).

Samhengisvíddin er samheiti yfir fyrirtækið í heild sinni, par á meðal stærð pess, framleiðslutækni, umhverfi, fyrirtækjamenningu, stefnu og markmið. Skipulags- og samhengisvíddir eru víxlháđar. Pannig hafa rannsóknir leitt í ljós að stór fyrirtæki eru líklegri til pess að vera formlegri, sérhæfðari og staðlaðri en minni fyrirtæki (Daft, 2013; Pugh, 1997). Nokkur munur virðist vera samkvæmt rannsóknum á stórum framleiðslufyrirtækjum (e. workflow bureaucracy), starfsmannaregluveldi (e. personell bureaucracy) eins og sjúkrahúsum og skólum par sem margir háskólamenntaðir starfsmenn starfa og fullu regluveldi (e. full bureaucracy) (Vassiliou, Alberts og Agre, 2015).

\subsection{Stærð fyrirtækja}

Við flokkun fyrirtækja á alpjóðlegum vettvangi eftir stærð peirra er litið til starfsmannafjölda, veltu og efnahagsreiknings. Almennt er viðmiðið að lítil og meðalstór fyrirtæki séu með færri en 250 starfsmenn, ársveltu undir 50 milljónum evra og efnahagsreikning undir 43 milljónum evra. Rúmlega 99\% af öllum fyrirtækjum innan Evrópusambandsins eru lítil eða meðalstór fyrirtæki (CSES, 2012). Hið sama virðist gilda á Íslandi, en lítil og meðalstór fyrirtæki eru stærsti vinnuveitandinn hér á landi. •að er ekki auðvelt að nálgast hagtölur um fyrirtæki hér á landi en Samtök atvinnulífsins fengu Hagstofu Íslands til að vinna fyrirtækjatölfræði fyrir samtökin árið 2013 og kom pá í ljós að um 90\% fyrirtækja á Íslandi eru örfyrirtæki með færri en 10 starfsmenn, 8,4\% fyrirtækja eru lítil, með færri en 50 starfsmenn, 1,6\% fyrirtækja eru meðalstór, með allt að 250 starfsmenn og einungis $0,4 \%$ fyrirtækja eru stór, pað er með yfir 250 starfsmenn (Samtök atvinnulífsins, 2014; Hagstofa Íslands, 2016b).

Rannsóknir hafa leitt í ljós að stærð fyrirtækja (mæld í fjölda starfsfólks) hefur mikil áhrif á skipulag peirra (Rutherford, McMullen og Oswald, 2001; Bolman og Deal, 2003). Eftir pví sem fyrirtæki stækka vex sérhæfing peirra, stöðlun eykst og samskipti verða formlegri. Pugh and Hickson (1976) telja að skýra megi pá próun á pann veg að pegar fyrirtæki stækki aukist samhæfingarvandi (e. coordination problems) peirra, par sem starfsfólk pekki ekki hvert annað persónulega. •að kalli á formlegar leiðir til samhæfingar, svo sem að skrá starfslýsingar, hafa reglur og skriflegar upplýsingar. Eins gerist pað iðulega á fjölmennum vinnustöðum að svipaðir atburðir gerast síendurtekið s.s. að taka á móti nýju starfsfólki, reikna laun, stemma af lánadrottna, senda reikninga, sinna viðskiptavinum, svara í síma, o.fl. og pví nauðsynlegt að hafa ferla í fyrirtækjunum. Mikið hagræði felst í pví að staðla hluti, skrá verkferla og móta leiðbeinandi reglur. Afleiðing pessa er eins og fyrr segir aukið regluveldi (Jones, 2013).

Fjöldi stjórnprepa helst í hendur við fjölda starfsmanna. Erlendar rannsóknir hafa leitt í ljós að fyrirtæki með 1.000 starfsmenn hafi allt að fjögur stjórnprep og að stjórnprepum fjölgi iðulega í sjö pegar starfsfólki fjölgi í 3.000 (Jones, 2013). Fá stjórnprep er dæmi um flatt skipulag sem auðveldar boðskipti milli undir- og yfirmanna og flýtir ákvarðanatöku, en eykur mjög álag á stjórnendur par sem peir stýra mörgum undirmönnum, peir hafa með öðrum orðum víða stjórnunarspönn (Pugh, 1997). 


\subsection{Kyn stjórnenda}

Í kjölfar efnahagshrunsins árið 2008 hefur umræðan aukist um lágt hlutfall kvenna við æðstu stjórn evrópskra fyrirtækja, bæði í stjórnum félaga sem og í framkvæmdastjórn. Ísland hefur ekki farið varhluta af peirri umræðu (Guðbjörg Linda Rafnsdóttir og Margrét Porvaldsdóttir, 2012).

Árið 2011 var hlutfall kvenna meðal framkvæmdastjóra á Íslandi um 20\%. Hlutfall kvenna í umræddum stöðum er að meðaltali hærra í litlum fyrirtækjum, en hlutfallið lækkar eftir pví sem fyrirtækin verða stærri (Hagstofa Íslands, 2012), öfugt við pað sem gerist í nágrannalöndunum (Jón Snorri Snorrason, 2011). Gögn frá Velferðarráðuneytinu (2015) styðja petta pví samkvæmt peim stýra konur fremur litlum fyrirtækjum en stórum. Petta má sjá á pví að í litlum fyrirtækjum, sem hafa færri en 50 starfsmenn, er hlutfall kvenna í æðstu stjórnendastöðu 22\%. Pær stýra 16\% fyrirtækja á Íslandi með 50-99 starfsmenn, 9\% stjórnenda í fyrirtækjum með 100-249 starfsmenn eru konur og einungis 8\% fyrirtækja með 250 starfsmenn eða fleiri er stjórnað af konum (Velferðarráðuneytið, 2015).

\subsection{Rekstrarumhverfi fyrirtækja}

Rekstrarumhverfi fyrirtækja hefur margvísleg áhrif á starf og skipulag peirra. Auðlindir á borð við hráefni, fjármagn, upplýsingar og mannauð purfa fyrirtæki að sækja til umhverfis síns, og pað hvort samkeppni eða fákeppni ríkir á markaði hefur einnig mikil áhrif á starfsemi peirra (Jones, 2013). Umhverfið getur einnig breyst skyndilega með lagasetningu, tækninýjungum eða jafnvel náttúruvá, líkt og pekkt er í ferðapjónustu, sérstaklega við gosið í Eyjafjallajökli 2010 (Icelandair, 2010), eða pað tekur hægfara breytingum eins og hjá mörgum opinberum stofnunum sem ekki búa við samkeppni. Fyrir vikið eru meiri líkur á pví að pau treysti á einfalt og vélrænt skipulag.

Fyrirtæki sem búa við miklar tæknibreytingar og sveiflur á markaði, svo sem tölvu- og fjarskiptafyrirtæki, búa við mun meiri óvissu. Pannig getur ný vara eða pjónusta orðið úrelt á tiltölulega skömmum tíma. Slík óvissa elur af sér meiri sveigjanleika í skipulagi (minni stöðlun og sérhæfingu) og flóknara skipulag. Til að flýta ákvarðanatöku og hraða samskiptum grípa stjórnendur til pess ráðs að auka sveigjanleika í stjórnskipulagi. Pá er valdinu dreift og millistjórnendur hvattir til að taka ákvarðanir er snerta rekstur, líkt og pekkist í lífrænu skipulagi. Skyndilegar breytingar ala af sér pörf fyrir að einstaklingum eða einingum sé falið að minnka áhættu og pannig verður skipulagið flóknara, sem kallar á aukna pörf fyrir samhæfingu (Bolman og Deal, 2003; Burns, 1997).

Á pví tímabili sem hér er undir, frá 2007 - 2016, hefur efnahagsumhverfið einkennst af umtalsverðum sveiflum. Árið 2007 var mikill uppgangstími í íslensku efnahagslífi og oft er talað um árið 2007 sem táknmynd um mikil umsvif og mikla einkaneyslu, sem einkenndist af neyslulánum og skuldsetningu fyrirtækja og almennings (Rannsóknasetur verslunarinnar, 2016). Pá varð efnahagshrun á Íslandi árið 2008 og niðursveifla og kreppa hafa einkennt hagkerfi heimsins, sér í lagi í hinum vestræna heimi. Kreppan hefur haft misjafnlega djúp áhrif á hin ýmsu hagkerfi, ríki og fyrirtæki og Ísland fór ekki varhluta af henni (Viðskiptaráð Íslands, 2015). Hagkerfi telst í niðursveiflu pegar pjóðarframleiðsla dregst saman á milli tímabila og hugtakið efnahagskreppa er notað til að lýsa alvarlegum samdrætti í hagkerfinu, en samdráttur pýðir að framleiðsla og pjónusta hefur dregist saman og miðast við fleiri en eina atvinnugrein (Abberger og Nierhaus, 2008). Fyrirtæki leitast við að bregðast við efnahagsprengingum með kostnaðaraðhaldi, eignastjórnun og öflun nýrra tekna (Hofer, 1980). Fyrirtæki sem hafa náð góðum árangri í niðursveiflu hafa verndað grunngerð rekstrar með 
lækkun kostnaðar, verndun lausafjárstöðu, endursamningum við birgja, bættri birgðastjórnun, slegið fjárfestingum á frest og verið með sveigjanlegt viðskiptamódel (Rhodes og Stelter, 2010). Stærri fyrirtæki geta selt eignir, endurskipulagt reksturinn og leitað leiða til að auka tekjur, á meðan minni fyrirtæki leitast við að lækka kostnað, breyta áherslum í rekstri og leita nýrra syllumarkaða (e. niche markets). Minni fyrirtæki eru frekar sveigjanlegri en stærri fyrirtækin og eiga oftar í nánum tengslum við viðskiptavini sína, sem hefur reynst mörgum árangursríkt pegar prengir að (DeDee og Vorhies 1998; Latham, 2009). Petta er afar áhugavert og vekur upp spurningar um pað hvort stjórnendur gangi enn lengra og breyti jafnvel skipulagsformi og skipuriti pegar prengir að, en slíkt hefur lítið verið rannsakað, pó svo að viðbrögð fyrirtækja við efnahagsprengingum hafi verið rannsökuð umtalsvert, sérstaklega með tilliti til niðurskurðar og breyttrar stefnu (Abberger og Nierhaus, 2008; Collins, 2009; Copeland, 2000 Hofer, 1980; Kaplan og Norton, 2008; Rigby, 2001; Rhodes og Stelter, 2010).

\subsection{Skipulagsform}

Margskonar stjórnskipulag stendur fyrirtækjum til boða og eru megindrættir peirra dregnir upp í skipuriti. Helstu skipulagsformin sem sett hafa verið fram eru starfaskipulag (e. functional structure), afurðaskipulag (e. divisional structure) fléttuskipulag (e. matrix structure), auk fleiri skipulagsforma. Afurðaskipulagið sundurgreinist í mörg undirform. Vöruskipulag (e. product structure) er eitt peirra og pað skiptist í framleiðsludeildaskipulag (e. product division), fjöldeildaskipulag (e. multidivisional) og teymisskipulag (e. product team). Svæðisskipulag (e. divisional structure) og markaðsskipulag (e. market structure) tilheyra einnig afurðaskipulagi. Hér að neðan verður fjallað um helstu skipulagsformin sem finna má í íslenskum fyrirtækjum, en ekki er tóm til að fjalla ítarlega um einkenni pessara skipulagsforma í löngu máli en helstu einkenni peirra eru eftirfarandi (Daft, 2013; Jones 2013; Daft, 2007; Larson og Gobelli, 1987; Williamson, 1975).

\subsubsection{Starfaskipulag}

Í starfaskipulagi er sambærilegum störfum innan fyrirtækis raðað saman í viðeigandi deildir, t.d. öll framleiðsla á sér eingöngu stað í framleiðsludeild og lýtur einum stjórnanda. Áhersla er lögð á markmið deilda eða starfseininga. Skipulagið hvetur til sérhæfingar meðal starfsmanna og hentar best í litlum eða meðalstórum fyrirtækjum sem framleiða tiltölulega fáar afurðir og búa við stöðugleika í umhverfi sínu. Helsti kostur pessa skipulags er stærðarhagkvæmni, en veikleikar pess eru að oft er takmörkuð samræming milli deilda og starfseininga. Раð bregst hægt við breytingum í ytra umhverfi, starfsfólk verður oft einhæft í störfum sínum og ákvarðanir geta verið seinvirkar, par sem ákvarðanir hafa tilhneigingu til að leita til æðstu stjórnenda.

\subsubsection{Framleiðsludeildaskipulag}

Segja má að framleiðsludeildaskipulag sé fyrsta skrefið í átt að afurðaskipulagi. Pá hefur fyrirtækið stækkað og stofnaðar hafa verið sér rekstrareiningar utan um ólíkan rekstur, en hagræði felst í pví að vera með sameiginlega stoðpjónustu, svo sem mannaráðningar, innkaup, fjármál, markaðsmál o.fl. 


\subsubsection{Afurðaskipulag}

Afurðaskipulag/fjöldeildaskipulag grundvallast á peim afurðum sem fyrirtækið framleiðir eða peirri pjónustu sem pað veitir. Helstu einkenni pessa skipulags eru að um hverja afurð eða vöru er mynduð sérstök rekstrareining sem inniheldur alla pá aðgerðapætti sem nauðsynlegir eru til að framleiða afurðina. Áherslan hér er á vörulínur. Slíkt fyrirkomulag er algengt í stórum fyrirtækjum sem framleiða margar vörutegundir. Umhverfi fyrirtækja sem nota afurðaskipulag einkennist oft af óstöðugleika, en skipulagið styður við sveigjanleika með dreifstýrðari ákvarðanatöku. Slíkt gerir pað að verkum að auðveldara er að bregðast við örum breytingum í umhverfinu. Baugur Group var dæmi um slíkt skipulag en par voru sérstakar rekstrareiningar um matvöru, fataverslanir o.fl. Helsti kostur afurðaskipulagsins er mikil aðlögunarhæfni par sem pað er vel sýnilegt viðskiptavinum og getur tekist á við breytilegt umhverfi. Helstu ókostir pessa skipulags eru að pað eyðir stærðarhagkvæmni innan fyrirtækja og erfitt getur verið að sampætta og staðla á milli vörulína. Slíkt eykur hættu á tvíverknaði innan fyrirtækja.

\subsubsection{Svæðisskipulag}

Svæðisskipulag er algengast í stórum fyrirtækjum og pví svipar mjög til afurðaskipulagsins og eru kostirnir svipaðir. Svæðisskipulag á vel við pegar fyrirtæki vilja samræma starfsemi sjálfstæðra rekstrareininga og dótturfyrirtækja sem starfa á tilteknum svæðum. Helstu kostir pess eru að áhersla er lögð á lárétta samræmingu rekstrareininga innan sama svæðis, en minni áhersla er lögð á samræmingu milli svæðanna sjálfra. Pannig getur hver eining framleitt og pjónustað eftir pörfum síns svæðis. Svæðisskipulag er algengt í bílaiðnaði og við sölu matvæla.

\subsubsection{Fléttuskipulag}

Fléttuskipulag felst í pví að nýta samtímis kosti starfa- og afurðaskipulags. Рað sem einkennir pað öðru fremur er að starfa- og afurðaskipulagið er notað jöfnum höndum, pannig að valdabrautir fléttast. Forsendur fyrir notkun fléttuskipulags er að umhverfið kalli á bæði nýsköpun og stærðarhagkvæmni, pannig að nýta purfi takmarkaðar auðlindir fyrirtækja. Fléttuskipulag er helst notað í meðalstórum fyrirtækjum með fáar vörulínur. Рað miðar að pví að auðvelda öll samskipti og samræmingu innan fyrirtækisins til að gera pví kleift að mæta ólíkum kröfum umhverfisins. Petta skipulag hentar best í flóknu og síbreytilegu umhverfi. Helsti vandi fléttuskipulags er að starfsmönnum finnst sem peir hafi tvo yfirmenn, fundir geta verið margir og lykilatriði er að starfsmenn geti unnið vel saman. Starfsfólk og stjórnendur sem starfa í fyrirtækjum með fléttuskipulag purfa að búa yfir talsverðri samskiptahæfni og polinmæði er mikill kostur, par sem ólík markmið geta valdið umtalsverðri togstreitu milli aðila.

Samkvæmt skipulagskenningum purfa stjórnendur að velja pað stjórnskipulag sem hentar best fyrir fyrirtæki peirra, í samræmi við starfsemi pess, umfang, rekstrarumhverfi, framleiðslutækni, fjölda starfsmanna, stjórnunarspönn, landfræðilega legu o.fl. (Daft, 2013: Jones, 2013). Par sem markmið greinarinnar er að bera saman skipulagsform (skipurit) íslenskra fyrirtækja á tímabilinu 2007-2016 með pví að bera saman tvær kannanir og greina hvort efnahagssveiflur hafi haft áhrif á skipulagsform peirra, eru eftirtaldar rannsóknarspurningar settar fram: 
- Hafa efnahagssveiflur áhrif á skipulag og skipurit íslenskra fyrirtækja?

- Velja stjórnendur minni fyrirtækja frekar starfaskipulag en stjórnendur í stærri fyrirtækjum?

- Hver eru áhrif stöðugleika í rekstrarumhverfi á skipulagsform fyrirtækja?

- Hefur konum í stjórnunarstöðum fjölgað á pví tímabili sem könnunin nær yfir?

Svörin við pessum spurningum koma frá tveimur ofangreindum könnunum höfunda, annars vegar frá árinu 2007 og hins vegar 2016, sem nánar er skýrt frá í rannsóknaraðferðum.

\section{Rannsóknaraðferðir}

Markmið rannsóknarinnar er að skoða skipulagsform íslenskra fyrirtækja og hvort pau hafi breyst frá fyrri könnun höfunda. Sú fyrri var framkvæmd í nóvember og desember árið 2007, og sú síðari í júní til ágúst 2016. Ákveðið var að senda út spurningalista í gegnum netpóst til pátttakenda, pví pannig er unnt að ná með nokkuð einföldum hætti til margra aðila og fá svör með tiltölulega skjótum hætti. Undirbúningur seinni rannsóknar hófst á vormánuðum 2016. Pann 20. júní var spurningalistinn sendur á netföng forsvarsmanna fyrirtækjanna í gegnum QuestionPro og lokaáminning var send á sömu netföng pann 17. ágúst 2016.

\subsection{Dátttakendur og heimtur}

Pýði könnunar sem framkvæmd var árið 2007 kom frá Ríkisskattstjóra sem var pversnið af íslenskum fyrirtækjum með fimm starfsmenn eða fleiri launpega árið 2006 og höfðu skilað inn launamiðum fyrir átta milljónir eða meira. Upprunalegur pýðislisti innihélt 5031 fyrirtæki og stofnanir á Íslandi. Úrtakið var síðan valið pannig að valin voru 890 fyrirtæki og stofnanir. Netföng voru fundin á heimasíðum fyrirtækjanna eða á já.is. Pannig fengust upplýsingar um 537 netföng sem var endanlegt úrtak. Landfræðileg dreifing fyrirtækja á netfangalistanum endurspeglaði mjög vel upprunalegt pýði. Ekki var mögulegt að fá frekara úrtak frá Ríkiskattstjóra og pví var leitað til Creditinfo árið 2016. Pví er ekki um parað gagnasett að ræða. Creditinfo valdi af handahófi 550 einkafyrirtæki. Fyrirtækin áttu að endurspegla skiptingu fyrirtækja milli landsvæða og atvinnuvega. Ekki tókst að hafa uppi á netföngum hjá öllum fyrirtækjum sem voru á listanum, auk pess sem eitt fyrirtæki var hætt rekstri og var pví endanlegur fjöldi í úrtaki 492 fyrirtæki. Spurningalisti rannsóknarinnar var sendur á forstjóra eða framkvæmdastjóra fyrirtækjanna. Í kynningartexta með spurningakönnuninni var óskað eftir pví að ef viðtakandi væri ekki rétti aðilinn til að svara könnuninni, pá myndi viðkomandi áframsenda erindið á réttan aðila. Forsvarsmenn 120 fyrirtækja svöruðu könnuninni og er pví svarhlutfallið rúm $24 \%$ eins og sjá má í töflu 1. Í töflu 2 má sjá lýsingu á pátttakendum eftir bakgrunnsbreytum.

Tafla 1. Úrtak og heimtur

\begin{tabular}{lrr}
\hline & 2007 & 2016 \\
\hline Upprunalegt úrtak & 890 & 550 \\
Fyrirtæki í rekstri með netföng & 481 & 492 \\
Svara ekki & 259 & 372 \\
Svara & 222 & 120 \\
\hline Svarhlutfall & $46,15 \%$ & $24,39 \%$ \\
\hline
\end{tabular}


Í könnuninni árið 2007 bárust svör frá stjórnendum í 222 fyrirtækjum og var svörunin pví 46,1\% í peirri könnun. Lægra svarhlutfall árið 2016 skýrist að mestu af tímasetningu könnunarinnar, p.e. að hún var framkvæmd að sumri til, á sumarleyfistíma, en fyrri könnunin fór fram í nóvember og desember árið 2007.

\subsection{Mælitæki og úrvinnsla}

Rannsóknin byggist eins og áður segir á spurningalista enda hentar sú aðferð vel í megindlegum rannsóknum sem pessari. Spurningalistinn byggði á eldri spurningalista sem lagður var fyrir stjórnendur fyrirtækja á Íslandi árið 2007.

Spurningalistinn 2016 fólst í 39 spurningum. Skiptust pær í bakgrunnsspurningar um stjórnendur og fyrirtækið, um stjórnskipulag og skipulagsbreytingar (8 spurningar) og um starfsmannamál (19 spurningar). Ekki verður fjallað um starfsmannamál í pessari grein. Spurningalistinn 2007 innihélt 44 spurningar (par af 7 spurningar um skipulagsmál) og voru 21 spurning eins á báđum listum og er hægt að bera saman svör við peim spurningum. Svarmöguleikar spurninganna voru allt frá pví að vera tveir (Já/Nei) og upp í tíu, par sem hægt var að velja mismunandi aðferðir t.d. við mat á umsækjendum við ráðningar. Í flestum spurningunum var stuðst við nafna- eða röðunarskala sem aðeins heimilar að reikna út fjölda, tíðni og að nota krosstöflur. Spurningar um skipulag byggðu flestar á fjögurra flokka Likertskala. Fjögurra flokka Likert-skali pótti henta best til að lýsa t.d. rekstrarumhverfi fyrirtækja (mjög stöðugt, frekar stöðugt, frekar óstöðugt, mjög óstöðugt), eða hversu formlegt fyrirtækið sé (mjög formlegt, frekar formlegt, fremur óformlegt, mjög óformlegt). Í spurningum um aldur, starfsaldur, fjölda starfsmanna og veltu var stuðst við millibils- og hlutfallslega skala par sem flóknari tölfræði er möguleg. Spurningalistinn var forprófaður í nokkrum fyrirtækjum og lagfærður lítillega í kjölfar pess. Spurningalistinn árið 2016 var byggður á listanum frá árinu 2007 hvað skipulag fyrirłækja varðar, en spurningu um skipulagsbreytingar síðustu fimm ár var bætt við. Nær pað tímabil til ársins 2011 og tekur pví til tímabils áður en uppsveifla hefst að nýju í íslensku efnahagslífi.

Við tölfræðilega úrvinnslu var algengast að reikna út fjölda og tíðni en krosstöflur voru oftast gerðar um tengsl skipulags við stærð, auk menntunar stjórnenda. P-gildi og kí-kvaðrat var jafnframt reiknað út.

Til að skera úr um marktækni milli hópa árið 2007 og árið 2016 var stuðst við tveggja hlutfalla próf.3 Par sem gögn voru ekki normaldreifð var Mann-Whitney U próf notað og reiknað út p-gildi. Ef p-gildi var minna en 0,001 pá er pað skrifað sem <0,001. Við gagnavinnsluna var tölfræðiforritið SPSS 21.0 notað.

\subsection{Réttmæti og áreiðanleiki}

Hugsmíðarréttmæti (e. construct vality) vísar til pess hvort verið sé að mæla pá hugsmíð sem ætlað var að mæla (Sigríður Halldórsdóttir og Sigurlína Davíðsdóttir, 2013). Hugsmíðin stjórnskipulag var aðgerðabundið í eftirfarandi spurningum: Hefur formlegt stjórnskipulag

$$
\text { Formúlaner: } z=\frac{p_{1}-p_{2}}{\sqrt{\frac{p_{1}\left(100-p_{1}\right)}{n_{1}}+\frac{p_{2}\left(100-p_{2}\right)}{n_{2}}}}
$$


(skipurit) verið sampykkt í fyrirtækinu?; hvers konar skipulag hefur verið sampykkt (spurningalistinn sýndi helstu gerðir skipurita, einnig var mögulegt að merkja við annað og útskýra frekar)?; hversu mörg stjórnprep eru í fyrirtækinu (framkvæmdastjóri, millistjórnandi og almennir starfsmenn eru t.d. prjú stjórnprep); hversu formlegt fyrirtækið er (mjög formlegt = margar skráðar reglur, óformlegt = fáar skráðar reglur)?; hversu sérhæfð eru störf í fyrirtækinu/stofnuninni (mikil sérhæfing = störf og verkefni eru sérhæfð og aðskilin, lítil sérhæfing = störf og verkefni skarast)? Allar pessar spurningar byggja á rannsóknum Pugh (1997).

Hugsmíðin rekstrarumhverfi fyrirtækja var aðgerðabundin í spurningunni: Er rekstrarumhverfi fyrirtækis/stofnunar stöðugt eða breytilegt? (Stöðugt = litlar breytingar um lengri tíma, óstöðugt = skyndilegar breytingar tíðar)? Pessi spurning byggist á Jones (2013).

Kyn stjórnenda var kannað með spurningunni: Ertu karl eða kona?

Stærð fyrirtækja var mæld með spurningunni: Hver var fjöldi starfsmanna að meðaltali í fyrirtækinu árið 2015 (svarendur slógu inn tölu)? Við úrvinnslu niðurstaðna var stuðst við stærðarflokkun CSES (2012).

Ytra rannsóknarréttmæti (e. exteranal validity) vísar til pess að hve miklu leyti við getum alhæft niðurstöður rannsóknar yfir á pýði (Sigríður Halldórsdóttir og Sigurlína Davíðsdóttir, 2013). Par eru a.m.k. tvær leiðir færar. Í fyrsta lagi að kanna hvort að svarendahópurinn sé sambærilegur úrtakinu eða pýðinu. Lágt svarhlutfall árið 2016 er ákveðið áhyggjuefni par sem pað eykur hættu á að svarendahópurinn sé skekktur miðað við úrtakshópinn. Ef hópurinn sem boðin var pátttaka í könnuninni 2016 er borinn saman við hópinn sem svaraði pá var ekki munur á landfræðilegri staðsetningu fyrirtækja (frávikin voru 1,5\%). Aftur á móti pá var munur á svörun eftir stærð pví minni fyrirtækin svöruðu hlutfallslega síður en pau stærri (allt að $10 \%$ frávik). Í úrtaki komu ekki fram upplýsingar um kyn stjórnenda og pví ekki hægt að bera saman hópa og úrtakið. Í öðru lagi er mögulegt að bera saman pá sem svöruðu snemma við pá sem svöruðu seint og athuga hvort að svör pessara tveggja hópa séu eins (Sivo, Saunders, Chang og Jiang, 2006). Sú aðferð byggir á peirri hugmynd að peir sem svara seint, t.d. eftir aðra eða priðju áminningu, hafi svipuð hegðunareinkenni og peir sem ekki svara könnuninni. Pegar borin voru saman svör fyrstu 20\% svarenda við svör seinustu 20\% svarendanna pá var bara marktækur munur á einni spurningu af 39. Einnig var bara marktækur munur á einni spurningu pegar fyrstu 50\% svarenda voru borin saman við seinni $50 \%$ svarenda. Út frá pessu er ólíklegt að svarendahópurinn sé pað skekktur að pað hafi áhrif á niðurstöður pó að ekki sé hægt að útiloka pað.

Áreiðanleiki fjallar um áreiðanleika tölfræðilegra mælinga (Sigríður Halldórsdóttir og Sigurlína Davíðsdóttir, 2013). Sú aðferð sem vísað er til hér að ofan, p.e. að bera saman fyrstu og síðustu pátttakendur, bendir til áreiðanleika niðurstaðna. Pá benda fyrri rannsóknir höfunda (Ingi Rúnar Eðvarðsson og Guðmundur Kristján Óskarsson, 2008) til svipaðra niðurstaðna. Рað eykur á áreiðanleika mælitækisins og gæti að einhverju leyti flokkast undir endurtekna prófun (e. test-retest) (Sigríður Halldórsdóttir og Sigurlína Davíðsdóttir, 2013).

\section{Niðurstöður}

\subsection{Fyrirtæki og stjórnendur}

Eins og fyrr segir bárust svör frá stjórnendum í 120 fyrirtækjum í könnuninni árið 2016 og frá 222 stjórnendum árið 2007. Í töflu 2 gefur að líta upplýsingar um pá stjórnendur sem tóku pátt í könnununum tveimur. Kvenstjórnendur sem svöruðu könnuninni 2016 voru 30\% og hafði 
peim fjölgað um 10\% á milli kannana. Рað er nokkuð hærra hlutfall kvenstjórnenda en kemur fram hjá Hagstofu Íslands (2016b), en árið 2015 voru konur 21,9\% framkvæmdastjóra í íslenskum fyrirtækjum. Meðalaldur stjórnenda 2016 var 50,9 ár og höfðu peir starfað 12,8 ár að meðaltali hjá fyrirtækinu, pví hefur aldur og starfsaldur aukist á milli kannana. Meðalaldur stjórnenda liggur ekki fyrir í gögnum Hagstofunnar en liðlega 60\% framkvæmdastjóra árið 2015 voru eldri en 45 ára (Hagstofa Íslands, 2016b). Mikill meirihluti stjórnenda hefur lokið háskólanámi og hefur pað hlutfall aukist milli kannana.

Tafla 2. Stjórnendur sem tóku pátt í könnununum 2007 og 2016

\begin{tabular}{lrrr}
\hline Stjórnendur & 2007 & 2016 & p-gildi \\
\hline Karlar (\%(fjöldi)) & $79,5 \%(171)$ & $70 \%(84)$ & $0,05^{*}$ \\
Konur & $20,5 \%(44)$ & $30 \%(36)$ & \\
& $100 \%(215)$ & $100 \%(120)$ & \\
Meðalaldur (meðaltal (staðlafrávik/fjöldi)) & $46,2(8,8 / 208)$ & $50,9(8,9 / 120)$ & $<0,001^{* *}$ \\
Meðalstarfsaldur í fyrirtæki & $9,8(8,7 / 190)$ & $12,8(10,2 / 120)$ & $0,012^{* *}$ \\
Grunnskólamenntun (\%(fjöldi)) & $5,1 \%(11)$ & $0,9 \%(1)$ & $0,008^{*}$ \\
Framhaldskólamenntun & $37 \%(80)$ & $25,6 \%(30)$ & \\
Háskólamenntun & $57,9 \%(125)$ & $73,5 \%(86)$ & \\
& $100 \%(216)$ & $100 \%(117)$ & \\
\hline
\end{tabular}

* Kí-kvaðrat próf. ${ }^{* *}$ Mann-Whitney U próf.

Fyrirtækin sem tóku pátt í könnununum árið 2007 og 2016 má sjá í töflu 3.

Tafla 3. Fyrirtækin sem tóku pátt í könnununum 2007 og 2016

\begin{tabular}{lrrr}
\hline & $\begin{array}{r}2007 \\
\%(f j o ̈ l d i)\end{array}$ & $\begin{array}{r}2016 \\
\%(f j o ̈ l d i)\end{array}$ & p-gildi \\
\hline Einkahlutafélag & $67,9 \%(144)$ & $80,0 \%(96)$ & $0,001^{*}$ \\
Almenningshlutafélag & $13,7 \%(29)$ & $15,8 \%(19)$ & \\
Annað & $18,4 \%(39)$ & $4,2 \%(5)$ & \\
& $100 \%(212)$ & $100 \%(120)$ & \\
Færri en 50 starfsmenn & $79,6 \%(168)$ & $65,0 \%(78)$ & $0,003^{*}$ \\
Á bilinu 50 - 250 starfsmenn & $18,0 \%(38)$ & $25,8 \%(31)$ & \\
Fleiri en 250 starfsmenn & $2,4 \%(5)$ & $9,2 \%(11)$ & \\
& $100 \%(211)$ & $100 \%(120)$ & \\
Meðalfjöldi starfsmanna (m (s/n)) & $59,4(323,5 / 211)$ & $83,5(192 / 120)$ & $0,001^{* *}$ \\
\hline
\end{tabular}

* Kí-kvaðrat próf. ${ }^{* *}$ Mann-Whitney U próf.

Af töflu 3 má ráđa að einkahlutafélög eru fleiri í könnuninni árið 2016 en árið 2007 og eins eru fyrirtæki með færri en 50 starfsmenn hlutfallslega færri árið 2016 en í könnunni 2007. Ef mið er tekið af gögnum Hagstofunnar pá voru 97\% íslenskra fyrirtækja með færri en 50 starfsmenn árið 2016 (Hagstofa Íslands, 2016b). 
Peir sem svara könnuninni árið 2016 hafa pannig pessi sérkenni: Hlutfallslega fleiri konur svara en pýðið segir til um og pátttakendur í könnuninni eru fulltrúar stærri fyrirtækja en algengt er að jafnaði á Íslandi.

\subsection{Skipulagsform íslenskra fyrirtækja}

Í könnuninni var spurt hvort skipulagsform (skipurit) hefði verið sampykkt í fyrirtækinu. Eins og áður segir nær skipurit til valdabrauta og formlegra samskipti innan fyrirtækja, hvaða starfsemi og starfsfólk tilheyri hvaða deild og er vettvangur upplýsingagjafar. Árið 2007 hafði skipurit verið sampykkt hjá 54,8\% peirra sem svöruðu könnuninni en hjá 45,2\% fyrirtækja hafði slíkt skipulag ekki verið sampykkt. Árið 2016 voru 58\% fyrirtækja með sampykkt stjórnskipulag sem er aukning, en munurinn er ekki marktækur á tveggja hlutfalla prófi $(p=0,575)$. Fyrirtæki með fleiri en 50 starfsmenn hafa oftar sampykkt stjórnskipulag en minni fyrirtæki. Pegar stuðst er við tveggja hlutfalla próf er munurinn marktækur $(p<0,001)$ bæði árið 2007 og árið 2016. Hið sama á við um háskólamenntaða stjórnendur sem mun oftar hafa hugað að formlegu skipulagi en stjórnendur með aðra menntun bæði árið 2007 og árið 2016 (Kí-Kvaðrat próf $\mathrm{p}=0,002$ og p=0,011). Pó ber að hafa í huga að stjórnendur stærri fyrirtækja sem tóku pátt í könnuninni hafa flestir lokið framhaldsskóla og eða háskólanámi. Ekki er sjáanlegur munur á pví hvort stjórnskipulag hafi verið sampykkt eftir starfsgrein fyrirtækja.

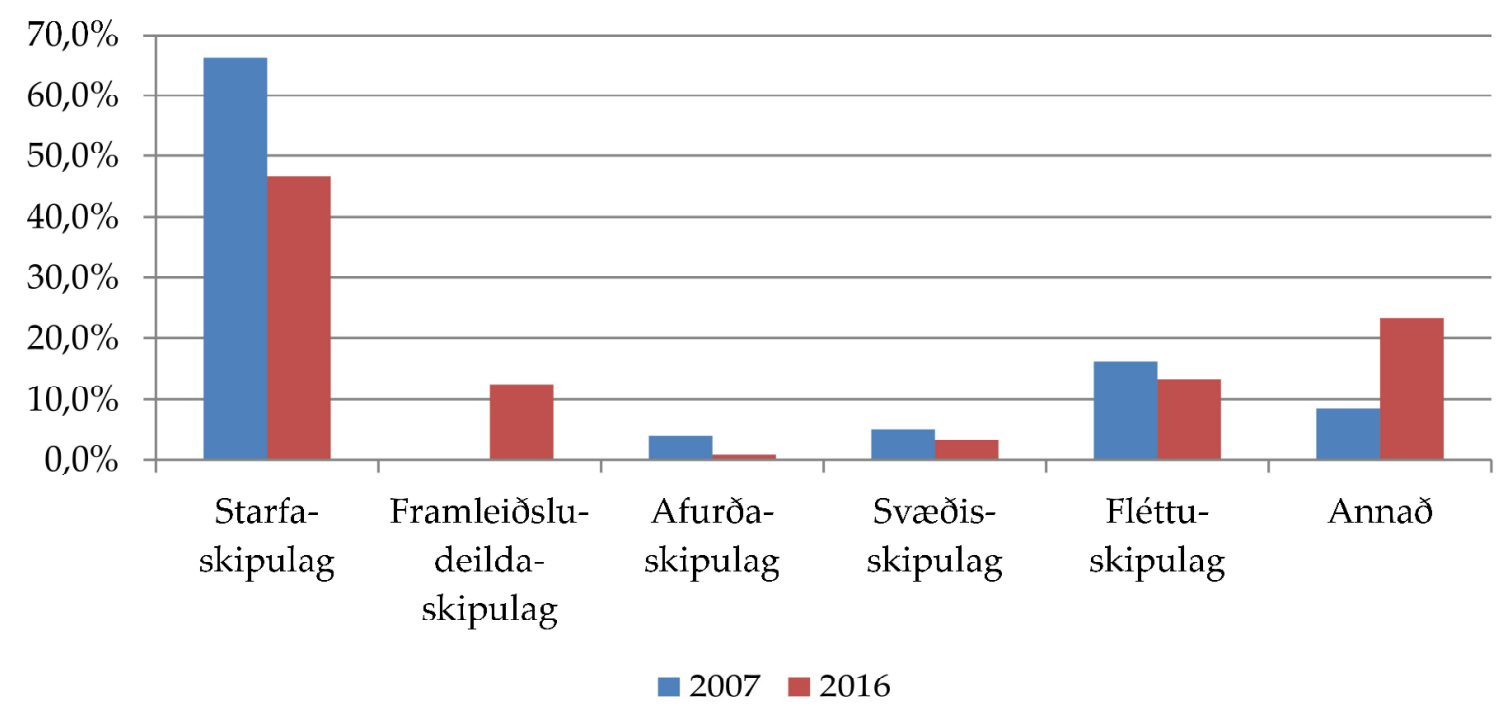

Mynd 1. Skipulagsform fyrirtækja 2007 og 2016

Flest fyrirtækin í könnuninni eru skipulögð í anda starfaskipulags (sjá mynd 1). Pað á við bæði árið 2007 og árið 2016. Í síðari könnuninni var svarmöguleikanum framleiðsludeildaskipulagi bætt við (í spurningalistanum voru myndir af skipuritum sem stjórnendur merktu við). Ætla má að ef pað hefði ekki verið gert myndu margir hafa merkt við starfaskipulag. Fléttuskipulag kemur pví næst og pá framleiðsludeildaskipulag.

Á spurningalistanum árið 2016 var spurningin: Hafa verið gerðar breytingar á stjórnskipulagi fyrirtækisins síðastliðin 5 ár? Alls svöruðu 120 stjórnendur pessari spurningu og sögðu 44 peirra eða 36,7\% að breytingar hefðu verið gerðar. Algengustu skipulagsbreytingar fólust í pví að yfirtaka annað fyrirtæki eða samruni við annað fyrirtæki (sjá töflu 4). 
Tafla 4. Hvaða breytingar hafa verið gerðar?

\begin{tabular}{lr}
\hline & Fjöldi $(\%)$ \\
\hline Yfirtaka á öðru fyrirtæki & $9(20,4 \%)$ \\
Samruni við annað fyrirtæki & $8(18,1 \%)$ \\
Skipulagseiningar hafa verið seldar út úr fyrirtækinu & $3(6,8 \%)$ \\
Ný deild/eining & $4(9,0 \%)$ \\
Vöxtur og skipulagsbreytingar & $3(6,8 \%)$ \\
Annað, hvað? & $17(38,6 \%)$ \\
Samtals & $44(100 \%)$ \\
\hline
\end{tabular}

\subsection{Fjöldi stjórnprepa}

Stjórnendur fyrirtækja voru spurðir um fjölda stjórnprepa í fyrirtækinu. Samkvæmt könnuninni hafa íslensk fyrirtæki tæplega prjú stjórnprep bæði árið $2007(2,88)$ og árið 2016 $(2,75)$ (almenna starfsmenn, millistjórnendur og framkvæmdastjóra/forstöðumann). Í nokkrum fyrirtækjum var einungis eitt stjórnprep, en sex prep pegar mest lét. Eins og sjá má í töflu 5 pá er fjöldi stjórnprepa mjög svipaður á milli kannana.

Tafla 5. Hversu mörg stjórnprep eru í fyrirtækinu 2007 og 2016

\begin{tabular}{lrrr}
\hline & $\begin{array}{r}2007 \\
\%(f j o ̈ l d i)\end{array}$ & $\begin{array}{r}2016 \\
\%(f j o ̈ l d i)\end{array}$ & p-gildi $^{*}$ \\
\hline Eitt & $5,3 \%(11)$ & $8,5 \%(10)$ & 0,600 \\
Tvö & $26,8 \%(56)$ & $24,6 \%(29)$ & \\
Prjú & $45,9 \%(96)$ & $50,8 \%(60)$ & \\
Fjögur & $19,6 \%(41)$ & $15,3 \%(18)$ & \\
Fimm & $1,9 \%(4)$ & $0,8 \%(1)$ & \\
Sex & $0,5 \%(1)$ & $0,0 \%(0)$ & \\
& $100 \%(209)$ & $100 \%(118)$ & \\
\hline
\end{tabular}

${ }^{*}$ Kí-kvaðrat próf.

\subsection{Skipulags- og samhengisvídd íslenskra fyrirtækja}

Í könnuninni voru stjórnendur spurðir út í nokkra pætti skipulagsvíddar. Spurt var um hversu formleg skipulagheildin væri, sérhæfingu viðfangsefna og háskólamenntun starfsmanna. 
Tafla 6. Hversu formlegt er fyrirtækið eftir stærð árið 2007 og árið 2016.

\begin{tabular}{|c|c|c|c|c|c|c|c|}
\hline & & $\begin{array}{c}\text { Mjög } \\
\text { formlegt } \\
\% \text { (fjöldi) }\end{array}$ & $\begin{array}{c}\text { Frekar } \\
\text { formlegt } \\
\%(\text { fjöldi) }\end{array}$ & $\begin{array}{c}\text { Frekar } \\
\text { óformlegt } \\
\%(f j o ̈ l d i) \\
\end{array}$ & $\begin{array}{c}\text { Mjög } \\
\text { óformlegt } \\
\text { \%(fjöldi) }\end{array}$ & & $\begin{array}{l}\mathrm{p}^{*} \\
\text { gildi }\end{array}$ \\
\hline 2007 & Öll fy & $2,3 \%(5)$ & $26,5 \%(57)$ & $48,4 \%(104)$ & $22,8 \%(49)$ & $100 \%(215)$ & 0,070 \\
\hline 2016 & Öll fyrirtæki & $5,9 \%(7)$ & $16,1 \%(19)$ & $50,8 \%(60)$ & $27,1 \%(32)$ & $100 \%(118)$ & \\
\hline \multirow[t]{3}{*}{2007} & Færri en 50 starfsmenn & $1,2 \%(2)$ & $19 \%(32)$ & $53 \%(89)$ & $26,8 \%(45)$ & $100 \%(168)$ & $<0,001$ \\
\hline & Á bilinu 50 - 250 starfsmenn & $8,3 \%(3)$ & $58,3 \%(21)$ & $27,8 \%(10)$ & $5,6 \%(2)$ & $100 \%(36)$ & \\
\hline & Fleiri en 250 starfsmenn & $0,0 \%(0)$ & $60,0 \%(3)$ & $20,0 \%(1)$ & $20,0 \%(1)$ & $100 \%(5)$ & \\
\hline \multirow[t]{3}{*}{2016} & Færri en 50 starfsmenn & $3,9 \%(3)$ & $11,7 \%(9)$ & $51,9 \%(40)$ & $32,5 \%(25)$ & $100 \%(77)$ & 0,269 \\
\hline & Á bilinu 50 - 250 starfsmenn & $10 \%(3)$ & $26,7 \%(8)$ & $50,0 \%(15)$ & $13,3 \%(4)$ & $100 \%(30)$ & \\
\hline & Fleiri en 250 starfsmenn & $9,1 \%(1)$ & $18,2 \%(2)$ & $45,5 \%(5)$ & $27,3 \%(3)$ & $100 \%(11)$ & \\
\hline
\end{tabular}

* Kí-kvaðrat próf.

Hversu formleg skipulagsheild er vísar til skráðra reglna, samskipta og starfslýsinga. Við spurningunni hversu formlegt er fyrirtækið, bárust í fyrri könnuninni, árið 2007, svör frá 215 stjórnendum en 120 stjórnendur svöruðu sömu spurningu árið 2016. Á spurningalistanum var gefin sú skýring að formlegt pýddi margar skriflegar reglur, en óformleg skipulagsheild skilgreind pannig að um fáar skriflegar reglur væri að ræða. Мiðað við pessi svör pá virðist sem dregið hafi úr formlegheitum milli kannana en munurinn er pó ekki marktækur.

Ef fyrirtækin eru flokkuð upp eftir stærð líkt og gert er í töflu 6, pá hefur stærð fyrirtækjanna ekki lengur áhrif á pað hversu formlegt fyrirtækið er. Stærri fyrirtækin voru formlegri en hin smærri árið 2007 og var munurinn marktækur $(p=<0,001)$. Árið 2016 var munurinn ekki lengur marktækur $(p=0,269)$.

\subsection{Menntun starfsfólks}

Menntun starfsfólks í fyrirtækjum lýsir vel sérkennum peirra og skipulagi. Í framleiðslufyrirtækjum er algengt að hlutfall háskólamenntaðra starfsmanna sé lágt, stöðlun mikil sem og verkaskipting, en algengara er að hlutfallið sé hátt í háskólum og sjúkrastofnunum, par sem viðfangsefnin eru flókin og stöðlun minni. Um helmingur fyrirtækjanna í könnuninni árið 2007 hafði 1-5 háskólamenntaða starfsmenn en 24,5\% fyrirtækja hafði engan háskólamenntaðan starfsmann. Hlutfall háskólamenntaðra starfsmanna var 25,7\% að meðaltali. Í könnuninni árið 2016 var hlutfall háskólamenntaðra starfsmanna næstum pví pað sama og í fyrri könnuninni eða 25,6\%, eins var um helmingur (50,8\%) fyrirtækjanna með 1-5 háskólamenntaða starfsmenn. Aðalmunurinn á milli kannananna er sá að nú eru einungis $11,7 \%$ fyrirtækja með engan háskólamenntaðan starfsmann sem er umtalsverð minnkun.

Stærð fyrirtækja skiptir ekki máli varðandi fjölda háskólamenntaðra starfsmanna í báðum könnunum. 
Tafla 7. Hversu sérhæfð eru störfin í fyrirtækinu 2007 og 2016

\begin{tabular}{lrrr}
\hline & 2007 & 2016 & p-gildi $^{*}$ \\
& $\%(f j o ̈ l d i)$ & $\%(f j o ̈ l d i)$ & \\
\hline Mjög sérhæfð & $20 \%(43)$ & $19,5 \%(23)$ & 0,998 \\
Frekar sérhæfð & $57,7 \%(124)$ & $58,5 \%(69)$ & \\
Frekar ósérhæfð & $19,5 \%(42)$ & $19,5 \%(23)$ & \\
Mjög ósérhæfð & $2,8 \%(6)$ & $2,5 \%(3)$ & \\
& $100 \%(215)$ & $100 \%(118)$ & \\
\hline
\end{tabular}

* Kí-kvaðrat próf.

Hjá flestum fyrirtækjunum sem pátt tóku í könnununum eru störfin frekar sérhæfð (57,7\% árið 2007 og 58,5\% árið 2016 ) eða mjög sérhæfð (20\% árið 2007 og 19,5\% árið 2016). Árið 2007 voru pað helst minni fyrirtækin sem voru með ósérhæfð störf, enda algengt að viðfangsefnin í slíkum fyrirtækjum séu mörg og starfsmenn fáir og purftu par af leiðandi að ganga í flest störf, en í könnuninni árið 2016 er sá munur ekki lengur til staðar. Ekki er munur milli starfsgreina hvað sérhæfingu starfa varðar og nánast enginn munur er frá fyrri rannsókn. Samhengisvíddin er samheiti yfir fyrirtæki í heild sinni, par á meðal stærð, framleiðslutækni, umhverfi, fyrirtækjamenningu, stefnu og markmið.

Tafla 8. Er rekstrarumhverfi fyrirtækisins stöðugt eða breytilegt árið 2007 og $2016 ?$

\begin{tabular}{lrrr}
\hline & 2007 & 2016 & p-gildi $^{*}$ \\
& $\%(f j o ̈ l d i)$ & $\%(f j o ̈ l d i)$ & \\
\hline Mjög stöðugt & $7,8 \%(17)$ & $5,9 \%(7)$ & 0,486 \\
Frekar stöðugt & $61,5 \%(134)$ & $61,9 \%(73)$ & \\
Frekar óstöðugt & $25,2 \%(55)$ & $29,7 \%(35)$ & \\
Mjög óstöðugt & $5,5 \%(12)$ & $2,5 \%(3)$ & \\
& $100 \%(218)$ & $100 \%(118)$ & \\
\hline
\end{tabular}

* Kí-kvaðrat próf.

Af töflu 8 má ráđa að mikill meirihluti fyrirtækja í báðum könnunum starfar í frekar stöðugu umhverfi eða rúm $61 \%$. Ekki fundust tengsl milli stærðar eða starfsgreinar fyrirtækja á rekstrarumhverfi. Munur milli kannana er mjög lítill.

Samkvæmt skipulagsfræðum pá hefur rekstrarumhverfi mikil áhrif á skipulag fyrirtækja. Pví stöðugra sem rekstrarumhverfið er peim mun staðlaðra og sérhæfðara ætti skipulag fyrirtækja að vera (Daft, 2007; Jones, 2013). Samkvæmt niðurstöðum pessara tveggja kannana hefur rekstrarumhverfi ekki áhrif á sérhæfingu fyrirtækja. Рað hafði hins vegar áhrif á stjórnskipulag fyrirtækja árið 2007, pá var marktækur munur $(\mathrm{p}=0,029)$. Aftur á móti pá er pessi munur ekki lengur til staðar árið 2016 ( $\mathrm{p}=0,642)$.

Fyrirtæki sem voru í óstöðugu rekstrarumhverfi voru auk pess mun óformlegri en pau sem voru í stöðugra rekstrarumhverfi árið 2007 (sjá töflu 9). Ekki er hægt að greina slíkan mun árið 2016. 
Tafla 9. Hversu formlegt er fyrirtækið eftir rekstrarumhverfi árin 2007 og 2016?

\begin{tabular}{lrrrrrr}
\hline & & $\begin{array}{c}\text { Mjög } \\
\text { formlegt } \\
\%(f j o ̈ l d i)\end{array}$ & $\begin{array}{c}\text { Frekar } \\
\text { formlegt } \\
\text { \%(fjöldi) }\end{array}$ & $\begin{array}{c}\text { Frekar } \\
\text { óformlegt } \\
\text { \%(fjöldi) }\end{array}$ & $\begin{array}{c}\text { Mjög } \\
\text { óformlegt } \\
\text { \%(fjöldi) }\end{array}$ & \\
\hline Mjög stöðugt & 2007 & $11,8 \%(2)$ & $35,3 \%(6)$ & $17,6 \%(3)$ & $35,3 \%(6)$ & $100 \%(17)$ \\
& 2016 & $0,0 \%(0)$ & $42,9 \%(3)$ & $42,9 \%(3)$ & $14,3 \%(1)$ & $100 \%(7)$ \\
Frekar stöðugt & 2007 & $2,3 \%(3)$ & $27,3 \%(36)$ & $49,2 \%(65)$ & $21,2 \%(28)$ & $100 \%(132)$ \\
& 2016 & $6,8 \%(5)$ & $12,3 \%(9)$ & $53,4 \%(39)$ & $27,4 \%(20)$ & $100 \%(73)$ \\
Frekar óstöðugt & 2007 & $0,0 \%(0)$ & $25,9 \%(14)$ & $57,4 \%(31)$ & $16,7 \%(9)$ & $100 \%(54)$ \\
& 2016 & $5,7 \%(2)$ & $20,0 \%(7)$ & $45,7 \%(16)$ & $28,6 \%(10)$ & $100 \%(35)$ \\
Mjög óstöðugt & 2007 & $0,0 \%(0)$ & $8,3 \%(1)$ & $41,7 \%(5)$ & $50,0 \%(6)$ & $100 \%(12)$ \\
& 2016 & $0,0 \%(0)$ & $0,0 \%(0)$ & $66,7 \%(2)$ & $33,3 \%(1)$ & $100 \%(3)$ \\
\hline
\end{tabular}

2007 Kí-kvaðrat próf $(p=<0,015) .2016$ Kí-kvaðrat próf $(p=0,712)$.

\section{Umræða}

Markmið greinarinnar er að bera saman kannanir frá árinu 2007 og árinu 2016 og greina hvort sveiflur í efnahagsumhverfi hafi áhrif á stjórnskipulag íslenskra fyrirtækja. Meginniðurstaðan er sú að mjög litlar breytingar hafi orðið á skipulagi fyrirtækja milli kannana. Hjá um 37\% fyrirtækja sem pátt tóku í könnuninni höfðu verið gerðar margvíslegar skipulagsbreytingar á síðustu fimm árum, svo sem yfirtaka á öðrum fyrirtækjum, samruni við önnur fyrirtæki eða að einingar höfðu verið seldar út úr fyrirtækinu. Ennfremur eru fleiri stjórnendur með háskólamenntun árið 2016 og svo virðist sem konum hafi fjölgað meðal stjórnenda á tímabilinu. Pá hafa fyrirtækin að jafnaði fleira starfsfólk í seinni könnunni heldur en árið 2007.

Samkvæmt rannsókninni hafa 58\% fyrirtækja sem tóku pátt í könnuninni sampykkt stjórnskipulag (skipurit). Fyrirtæki með fleiri en 50 starfsmenn og háskólamenntaða stjórnendur höfðu frekar sampykkt stjórnskipulag en önnur fyrirtæki, en lítill munur var á milli kannana árið 2007 og árið 2016, hvað petta varðar.

Flest fyrirtækin í könnuninni eru skipulögð í anda starfaskipulags og á pað bæði við árið 2007 og árið 2016. Í síðari könnuninni var svarmöguleikanum framleiðsludeildaskipulagi bætt við. Ætla má að ef pað hefði ekki verið gert myndu margir hafa merkt við starfaskipulag. Fléttuskipulag kemur pví næst og pá framleiðsludeildaskipulag. Minni fyrirtæki skipuleggja starfsemi sína í anda starfaskipulags í ríkari mæli en stærri fyrirtæki, sem eru líklegri til að hafa fléttuskipulag. Íslensk fyrirtæki hafa að meðaltali prjú stjórnprep og fjöldi stjórnprepa helst í heldur við fjölda starfsmanna í fyrirtækjum.

Hér verða helstu niðurstöður dregnar saman í samræmi við rannsóknarspurningar. Eins og fyrr segir pá hafa sveiflur í efnahagslífi ekki mikil áhrif á skipulag íslenskra fyrirtækja. Líkleg skýring á pví er að fyrirtækin í könnuninni hafa innan við 100 starfsmenn að meðaltali. Pað felur líklega í sér að pau fyrirtæki séu með eina eða mjög fáar framleiðsluvörur. Við slíkar aðstæður hentar starfaskipulagið best (Jones, 2013) óháð pví hvort sveiflur séu í viðskiptaumhverfi eða ekki. Sum fyrirtækjanna í könnuninni höfðu pó brugðist við breytingum í efnahagslífinu, með pví að sameinast öðrum fyrirłækjum, kaupa önnur fyrirtæki eða með pví að selja einingar út úr rekstrinum. Рað eru vel pekktar aðgerðir til að bregðast við efnahagssamdrætti (DeDee og Vorhies 1998; Latham, 2009; Rhodes og Stelter, 2010). 
Flest fyrirtækin í könnuninni höfðu prjú stjórnprep. Раð pýðir að yfirbygging peirra er lítil og pau eru tiltölulega sveigjanleg pannig að pau geta auðveldlega brugðist við sveiflum í efnahagslífi (Bolman og Deal, 2003; Burns, 1997).

Orðtakið margt smátt gerir eitt stórt á án efa við um fyrirtækjaumhverfi á Íslandi, pví að lítil og meðalstór fyrirtæki eru burðarás í íslensku atvinnulífi. Pannig eru ríflega 99\% allra starfandi fyrirtækja hér á landi lítil eða meðalstór. Hér er um fjölbreytta flóru fyrirtækja að ræða sem stendur undir stórum hluta innlendrar verðmætasköpunar. Stærð fyrirtækjanna hafði áhrif á marga pætti skipulags. Stærri fyrirtækin eru formlegri og sérhæfðari en minni fyrirtækin. Pau hafa einnig oftar sampykkt stjórnskipulag, eru skipulögð í anda fléttuskipulags, og hafa prjú eða fleiri stjórnprep. Pær niðurstöður eru mjög í anda erlendra rannsókna (Rutherford, McMullen og Oswald, 2001; Bolman og Deal, 2003).

раð hversu formlegar skipulagsheildir eru, vísar til skráðra reglna, samskipta og starfslýsinga. Miðað við pessi svör stjórnenda pá virðist sem dregið hafi úr formlegheitum milli kannana árið 2007 og árið 2016, en munurinn er pó ekki marktækur. Ein skýring á pví kann að liggja í pví að svarendur í síðari könnuninni árið 2016 voru hlutfallslega fleiri úr stærri fyrirtækjum. Sem fyrr segir pá eykst samhæfingarvandi innan fyrirtækja eftir pví sem starfsfólki fjölgar, par sem starfsfólk pekkist ekki persónulega og einnig koma sömu viðfangsefni fyrir aftur og aftur. Skráðar reglur, starfslýsingar, skipurit og skriflegar upplýsingar auðvelda mjög starf á fjölmennum vinnustöðum eins og áður hefur komið fram (Pugh og Hickson, 1976).

Rekstrarumhverfi fyrirtækja hefur áhrif með peim hætti að starfaskipulag er algengara í stöðugu rekstrarumhverfi og einnig eru fyrirtæki í óstöðugu umhverfi óformlegri en önnur fyrirtæki. Samsvörun virðist pví vera á milli stjórnskipulags og rekstrarumhverfis hér á landi. Erlendar rannsóknir sýna fram á ápekkar niðurstöður (Bolman og Deal, 2003; Burns, 1997).

Hlutur kvenstjórnenda í könnuninni árið 2016 var 30\% og jókst hann um 10 prósentustig frá fyrri könnun. Skýringar á pví eru ekki einhlítar. Lög um kynjakvóta í stjórnum fyrirtækja sem sett voru árið 2013 gætu hafa leitt til aukinna ráðninga kvenstjórnenda á síðustu árum, pótt slík lagasetning hafi ekki bein áhrif á ráðningu í stjórnendastöður innan fyrirtækja. Раð væri pó í andstöðu við pað sem greint var frá hér að ofan að stjórnendur stærri fyrirtækja hafi frekar svarað könnuninni, pví konur stýra frekar minni fyrirtækjum á Íslandi, heldur en peim stærri eins og fram hefur komið (Guðbjörg Linda Rafnsdóttir og Margrét Porvaldsdóttir, 2012; Velferðarráðuneytið, 2015). Ekki er hægt að útiloka að konur hafi svarað könnuninni í ríkari mæli en karlar, par sem stjórnendur voru beðnir að áframsenda könnunina, væru peir ekki réttir aðilar til að svara, en ekki er mögulegt að kanna pað með pau gögn sem fyrir liggja.

Ein niðurstaða sem birtist í samanburði á könnununum er að menntun hefur aukist meðal íslenskra stjórnenda hin síðari ár. Aukin menntun stjórnenda gæti skýrst af pví að fleiri hafa sótt sér háskólamenntun eftir efnahagshrunið árið 2008. Pá gæti skýringin einnig legið í pví að stjórnendur í minni fyrirtækjunum svara síður í könnuninni árið 2016, en háskólamenntun er að jafnaði algengari meðal stjórnenda í stærri fyrirtækjum.

Frekari rannsókna er pörf á skipulagi íslenskra fyrirtækja. Pannig væri áhugavert að kafa dýpra ofan í einstaka pætti rannsóknarinnar með viðtölum og vinnustaðagreiningum.

Allar rannsóknir eru takmörkunum háðar. Í síðari könnuninni má segja að lágt svarhlutfall dragi úr peirri vissu sem hægt er að álykta með út frá niðurstöðum. Einnig ber að hafa í huga að konur svara könnuninni hlutfallslega frekar en karlar, fáir stjórnendur úr minnstu fyrirtækjunum og tiltölulega fáir stjórnendur pjónustufyrirtækja svara seinni könnuninni. Niðurstöður byggja aðallega á nafnabreytum og pað kallar á varfærni við að yfirfæra niðurstöður yfir á íslensk fyrirtæki almennt séð. Að lokum má nefna að niðurstöður 
könnunarinnar árið 2016 eru mjög svipaðar og í könnuninni frá árinu 2007 par sem svörun var liðlega 46\% og í samræmi við erlendar rannsóknir um skipulagsform fyrirtækja (Jones, 2013; Pugh, 1997).

Segja má að hagnýtt gildi pessarar rannsóknar felist einkum í pví að auka enn frekar við pekkingu á skipulagsformum fyrirtækja, en eins og bent hefur verið á eru rannsóknir á pví sviði afar fáar hér á landi. Aukin pekking getur ýtt undir markvissa ákvarðanatöku stjórnenda um hvaða stjórnskipulag hentar peirra skipulagsheild. Hvað varðar val á stjórnskipulagi má segja að sá páttur sem mótar ákjósanlegt stjórnskipulag er aðallega fjöldi framleiðsluvara og samskipti við neytendur. Í peim tilvikum par sem framleiðsluvörur eru fáar, eins og háttar til í meirihluta íslenskra fyrirtækja, hentar starfaskipulag best. Slíkt skipulag tryggir stærðarhagkvæmni og gæði vöru og pjónustu í gegnum sérhæfingu deilda. Рað veitir neytendum gæðavöru á samkeppnishæfu verði. Pegar framleiðsluvörum fjölgar, sem gerist iðulega pegar fyrirtæki stækka og velta eykst, parf að huga að skipulagi sem nær að fanga óskir viðskiptavina fyrir hverja vöru fyrir sig. Par henta ólíkar gerðir afurðaskipulags best. Pá má einnig halda pví fram að viðskiptaumhverfið hafi áhrif á skipulag með ýmsum hætti. Í peim tilvikum par sem viðskiptaumhverfið er stöðugt hentar starfaskipulagið mjög vel, en pegar krafa er um mikla vörupróun og tækninýjungar pá parf að skipta yfir í fléttuskipulag og jafnvel afurðaskipulag. Flest íslensk fyrirtæki hafa brugðist við óskum neytenda um vörupróun með fléttuskipulagi og framleiðsludeildarskipulagi par sem framleiðsluvörur eru oftast fáar og veltan ekki næg til að standa undir afurðaskipulagi.

\section{Heimildir}

Abberger, K. og Nierhaus, W. (2008). How to Define a Recession? CESifo Forum, 9(4), 74-76.

Alpýðusamband Íslands (2016). Horfur í efnahagsmálum. Hagspá ASÍ 2016-2018. Sótt 2. nóvember 2016 af: http://www.asi.is/media/299189/AS\%C3\%8D_vorspa20162018_lok.pdf

Arney Einarsdóttir, Ásta Bjarnadóttir, Katrín Ólafsdóttir, Anna Klara Georgsdóttir (2012). Staða og próun mannauðsstjórnunar á Íslandi: Cranet rannsóknin 2012.

Arney Einarsdóttir, , Katrín Ólafsdóttir, Auður Arna Arnardóttir (2011). Frá mjúkum yfir í harðar samdráttaraðgerðir á vinnumarkaði Sveigjanleiki fyrirtækja og stofnana í kjölfar hruns. Stjórnmál \& Stjórnsýsla: 2. tbl., 7. árg. 2011 (327-346).

Ásta Dís Óladóttir, (2010). Internationalization from a small domestic base: An empirical analysis of Economics and Management. Ph.D series 4.2010. Copenhagen Business School.

Bolman, L. G. og Deal, T. E. (2003). Reframing Organizations: Artistry, Choice and Leadership. San Fransisco: Jossey-Bass.

Buchanan, D. og Huczynski, A. (2013). Organizational Behaviour (8. útgáfa). London: Prentice Hall.

Burns, A. C. og Bush, R. F. (2003). Marketing Research: Online research applications. Upper Saddle River, N.J.: Prentice Hall.

Burns, T. (1997). Mechanistic and organismic structures. Í Pugh, D. S (ristj.) Organization Theory: Selected Readings. London: Penguin Books.

CSES. (2012). Evaluation of the SME Definition. Sótt 6.desember 2016 af http://ec.europa.eu/smart-

regulation/evaluation/search/download.do;jsessionid=Qtwq6mR9YY3LiqE-

x0HgZ7IuY8okMQkLU6QCon2rTMZ1EocSiJud!1168777535?documentId=9397527 
Child, J. (1972). Organizational Structure, Environment and Performance: The Role of Strategic Choice. Sociology vol. 6 no. 1 1-22

Collins, J. (2009). How the mighty fall - and why some companies never give in. London: Random House Business Books.

Copeland, T. (2000). Cutting Costs Without Drawing Blood. Harvard Business Review, 78 (5), 155-164.

Daft, R. L. (2013). Organizational Theory and Design. South- Western Cengage Learning.

Daft, R. L. (2007). Understanding the Theory and Design of Organizations, Mason: Thompson South-Western Publishing.

DeDee, J.K. og Vorhies, D.W. (1998). Retrenchment Activities of Small Firms during Economic Downturn: An Emperical Investigation. Journal of Small Business Management, 36(3), 46-61.

Duncan, R. (1979). What is the right organization structure? Decision tree analysis provides the answer. Organizational Dynamics, 7, (3), 59-80.

Einar Svansson og Runólfur Smári Steinpórsson (2012). Skipulag íslenskra fyrirtækja 20042007. Stjórnmál og stjórnsýsla ; 8 (2): s. 515-542

Guðbjörg Linda Rafnsdóttir og Margrét Porvaldsdóttir (2012). Kynjakvótar og mögulegar hindranir á leið kvenna til æðstu stjórnunar. Íslenska pjóðfélagið, 3. árgangur 2012, 57-76.

Gylfi Magnússon (2010). Morguninn eftir Ponzi. Tímarit um Viðskipti og Efnahagsmál: 7 (2): s. 11-32

Hagstofa Íslands (2016a). Spáð er að hagvöxtur verði 4,8\% árið 2016 og 4,4\% árið 2017. Sótt 4. nóvember 2016 af https:/hagstofa.is/utgafur/frettasafn/thjodhagsspa/thjodhagsspa-advetri-2016/

Hagstofa Íslands (2016b) Framkvæmdastjórar og stjórnarmenn fyrirtækja eftir kyni og aldri 19992015. Sótt 25. september 2016 af

http://px.hagstofa.is/pxis/pxweb/is/Atvinnuvegir/Atvinnuvegir_fyrirtaeki_fjoldi_stjornir/ FYR06101.px/?rxid=280183ee-40ab-4561-804d-36bfbfb1428c

Hagstofa Íslands (2016c). 4\% launagreiðenda með 50 eða fleiri launpega. Sótt 10. nóvember 2016 af https://hagstofa.is/utgafur/frettasafn/fyrirtaeki/fjoldi-launagreidenda-og-launthega/

Hagstofa Íslands (2015). Skipting atvinnugreina og starfandi fólks 2014. Sótt 22. júní 2016 af http://px.hagstofa.is/pxis/pxweb/is/Samfelag/Samfelag_vinnumarkadur_vinnumarkad ur/VIN01106.px/table/tableViewLayout1/?rxid=b053a753-7f0b-4fba-9a66-3e4c46633e03 
Hagstofa Íslands (2012). Kyn framkvæmdastjóra og stjórnarmanna eftir stærð fyrirtækja 2012. Sótt 31. ágúst 2016 af:

http://px.hagstofa.is/pxis/pxweb/is/Atvinnuvegir/Atvinnuvegir_fyrirtaeki_fjoldi_stjo rnir/FYR06102.px/table/tableViewLayout1/?rxid=06de2d81-c9c4-424f-be70-d062a5353d64

Hersey, P. og Blanchard, K. H. (1988). Management of organizational behavior: Utilizing Human Resources. Englewood Cliffs, N.J.: Prentice Hall.

Hofer, C. (1980). Turnaround Strategy. Journal of Business Strategy, 1(1), 19-31.

Holst, E. (2006). Women and Managerial Positions in Europe: Focus on Germany. Management Revue, 17, 2. 122-142.

Icelandair (2010). Icelandair and the Eyjafjallajökull volcanic eruption in 2010. Sótt 25. nóvember 2016 af: http://www.icelandair.is/specials/pages/is/eyjafjallajokull/

Ingi Rúnar Eðvarðsson og Guðmundur Kristján Óskarsson (2009). ,Íslenskir stjórnendur: einkenni, stjórnunaraðferðir og árangur. Bifröst Journal of Social Science. 3(1) : 45-65

Ingi Rúnar Eðvarðsson og Guðmundur Kristián Óskarsson (2008). Skipulagsform íslenskra fyrirtækja. Bifröst Journal of Social Science. 2(1) : 5-26

Ingi Rúnar Eðvarðsson (2006). Stjórnunaraðferðir og skipulag íslenskra fyrirtækja. Tímarit um viðskipti og efnahagsmál, útgáfa 2006, 3-26.

Jones, G. R. (2013). Organizational Theory, Design, and Change. (7. útgáfa). PEARSON

Jón Snorri Snorrason. (2011). Kynjahlutföll í stjórnum fyrirtækja. Bls. 184-193 í Ingjaldur Hannibalsson (ritstj.), Pjóðarspegillinn 2011, Rannsóknir í félagsvísindum XII, Viðskiptafræðideild. Reykjavík: Félagsvísindadeild. Sótt 25. september 2016 af

http://skemman.is/stream/get/1946/10259/25577/1/Rannsoknir_i_felagsvisindum_XII_Vidskip tafraedideild.pdf.

Kaplan, R. og Norton, D.P. (2008). Unconventional Wisdom in a Downturn. Sótt 20. september 2016 frá Harvard Business Review Online: http://www.hbr.org/2008/12/unconventionalwisdom-in-a-downturn/ar/1

KPMG Consulting (2000). Knowledge Management Research Report 2000. Annapolis/London.

Latham, S. (2009). Contrasting Strategic Response to Economic Recession in Start-Up versus Established Firms. Journal of Small Business Management, 47, (2), 180-201.

Larson, E.W. og Gobelli, H.H. (1987). „Matrix Management: Contradictions and Insights," California Management Review. (Summer 1987), 126-138.

Lim, K. K. og Ahmed, P. K. (2000). Enabling knowledge management: a measurement perspective. ICMIT 2000. Sótt 14. apríl 2016 af http://ieeexplore.ieee.org/iel5/7328/19806/00916781.pdf

Neubert, M.J., Hunter, E.M, Tolentino, R.C. (2016). A servant leader and their stakeholders: When does organizational structure enhance a leader's influence?, The Leadership Quarterly (2016), http://dx.doi.org/10.1016/j.leaqua.2016.05.005

Nilsson, F. og Kald, M. (2002). Recent Advances in Performance Management: The Nordic Case. European Management Journal, 20 (3), 235-245.

Pugh, D. S. (1997). Does context determine form? Í Pugh, D. S (ristj.) Organization Theory: Selected Readings. London: Penguin Books.

Pugh, D. S. og Hickson, D. J. (1976). Organizational structure in its context: The Aston programme I. Saxon House: Lexinton Books.

Rannsóknasetur verslunarinnar (2016). Árbók verslunarinnar: Hagtölur um íslenska verslun. Rannsóknasetur verslunarinnar. Háskólinn á Bifröst. Sótt 22. nóvember 2016 af http://www.rsv.is/files/Skra_0076049.pdf

Rannsóknarsetur vinnuréttar og jafnréttismála (2007). Jafnréttiskennitalan: Birting upplýsinga um jafnrétti i 100 stærstu fyrirtækjum á Íslandi. Bifröst: Háskólinn á Bifröst. 
Rhodes, D., \& Stelter, D. (2010). Accelerating Out of the Great Recession: How to Win in a SlowGrowth Economy. [Kindle útgáfa]. New York: McGraw-Hill.

Rigby, D. (2001). Moving Upward in a Downturn. Harvard Business Review, 79 (6), 98-105.

Rutherford, M. W., McMullen. P., and Oswald, S. (2001) 'Examining the Issue of Size and the Small Business: A Self Organizing Map Approach' Journal of Business and Economic Studies 7(2): 64-81.

Samtök atvinnulífsins. (2014). Vægi lítilla og meðalstórra fyrirtækja. Ísland og alpjóðlegur samanburður. Sótt pann 6. desember 2016 af http://www.sa.is/frettatengt/frettir/mikilgroska-a-litla-islandi/

Sigríður Halldórsdóttir og Sigurlína Davíðsdóttir (2013). Réttmæti og áreiðanleiki í megindlegum og eigindlegum rannsóknum. Í Sigríður Halldórsdóttir (ritstj.), Handbók í aðferðafræði rannsókna (bls. 211-227). Akureyri: Háskólinn á Akureyri.

Sivo, S., Saunders, C., Chang, Q. \& Jiang, J. J. (2006). How low should you go? Low response rates and the validity of inference in IS questionnaire research. Journal of Association for Information Systems, 7, 351-414.

Vassiliou,M.S., Alberts, D.S., Agre, J.R., (2015). C2 Re-envisioned: The Future of the Enterprise. CRC Press. Taylor \& Francis Group.

Velferðarráðuneytið (2015). Staða kvenna og karla á íslenskum vinnumarkaði. Staðreyndir og staða pekkingar.https://www.velferdarraduneyti.is/media/rit-og-skyrslur-

2015/Stada_karla_og_kvenna_29052015.pdf

Viðskiptaráð Íslands (2015). Ferð án fyrirheits: rekstur í efnahagslegu umróti. Skoðun Viðskiptaráðs, 23. nóvember 2015. Sótt 22. nóvember 2016 af: http://vi.is/\%C3\%BAtg\%C3\%A1fa/skodanir/ferd_an_fyrirheits.pdf

Williamson, O.E. (1975). Markets and Hiearchies: Analysis and Antitrust Implications. New York: Free Press. 